\title{
Seed Treatment with Ethanol Extract of Serratia marcescens is Compatible with Trichoderma Isolates for Control of Damping-off of Cucumber Caused by Pythium ultimum
}

Daniel P. Roberts, Sustainable Agricultural Systems Laboratory; Dilip K. Lakshman, Sustainable Agricultural Systems Laboratory and Florist and Nursery Plants Research Unit; Laurie F. McKenna, Sarah E. Emche, and Jude E. Maul, Sustainable Agricultural Systems Laboratory; and Gary Bauchan, Electron and Confocal Microscopy Unit, United States Department of Agriculture-Agricultural Research Service, Henry A. Wallace Beltsville Agricultural Research Center, Beltsville, MD 20705

\begin{abstract}
Roberts, D. P., Lakshman, D. K., McKenna, L. F., Emche, S. E., Maul, J. E., and Bauchan, G. 2016. Seed treatment with ethanol extract of Serratia marcescens is compatible with Trichoderma isolates for control of damping-off of cucumber caused by Pythium ultimum. Plant Dis. 100:1278-1287.

Environmentally friendly control measures for soilborne plant pathogens are needed that are effective in different soils when applied alone or as components of an integrated disease control strategy. An ethanol extract of Serratia marcescens N4-5, when applied as a cucumber seed treatment, effectively suppressed damping-off caused by Pythium ultimum in potting mix and in a sandy loam soil. Plant stand associated with this treatment was similar to that of seed treated with the chemical pesticide Thiram in the sandy loam soil. The N4-5 ethanol extract did not consistently provide significant disease control in a loam soil. The N4-5 ethanol extract was

compatible with two Trichoderma isolates, not affecting in vitro or in situ colonization of cucumber by these biological control fungi. Control of damping-off of cucumber was never diminished when this ethanol extract was applied as a seed treatment in combination with in-furrow application of the Trichoderma isolates, and disease control was improved in certain instances with these combinations in the loam soil. Data presented here indicate that the N4-5 ethanol extract is compatible with certain beneficial fungi, suggesting that this extract can be used as a component of integrated disease control strategies featuring biological control fungi.
\end{abstract}

Pythium ultimum Trow is an important soilborne oomycete capable of causing disease under favorable environmental conditions on more than 300 diverse plant species (Kamoun et al. 2015; Okubara et al. 2014). This ubiquitous necrotrophic pathogen is a common inhabitant of field soil, streams, and ponds and is capable of growing saprophytically on plant residue and of resisting adverse environmental conditions for long periods (Kamoun et al. 2015; Stanghellini and Hancock 1971). A large portion of the life cycle of $P$. ultimum is spent in a dormant state as sporangia or oospores. Exudates from seed or young roots of a suitable host trigger germination by these resting structures (Nelson 1990, 2004; Stanghellini 1974), which can result in seed and seedling damping-off, root pruning, and reduced yield (Kamoun et al. 2015).

Control of soilborne necrotrophic plant pathogens such as $P$. ultimum can be difficult (Okubara et al. 2014). The ability of $P$. ultimum to cause disease on a wide variety of crop species and to persist in soil confounds the use of rotation as a control measure. Cultivars resistant to the pathogen are limited in effectiveness (Louws et al. 2010; Lucas and Griffiths 2004; Okubara et al. 2014; Wang and Davis 1997). Cultural practices such as plowing to bury infected crop residue reduced disease incidence but was shown to be regionally inconsistent (Abawi 1991; Lewis et al. 1983; Sumner et al. 1986). Seed treatments, especially with mefenoxam when available, can be very effective in managing damping-off caused by Pythium spp. (Garzón et al. 2011). However, there are concerns regarding the development of resistance in pathogen populations (Lamour and Hausbeck 2000; Moorman and Kim 2004; Okubara et al. 2014; Taylor et al. 2002), and pesticides

Corresponding author: D. P. Roberts; E-mail: dan.roberts@ars.usda.gov

*The $\boldsymbol{e}$-Xtra logo stands for "electronic extra" and indicates that one supplementary table is published online.

Accepted for publication 30 December 2015.

http://dx.doi.org/10.1094/PDIS-09-15-1039-RE

This article is in the public domain and not copyrightable. It may be freely reprinted with customary crediting of the source. The American Phytopathological Society, 2016. may not be used in organic production systems. Biologically based control methods such as microbial biological control agents and organic amendments suffer from inconsistent performance (Bonanomi et al. 2007; Roberts and Kobayashi 2011) and, in the case of organic matter amendments, can take several years before they are effective (Bonanomi et al. 2007; Stone et al. 2001; Termorshuizen et al. 2006). Clearly, additional and more consistently effective control measures need to be developed for $P$. ultimum.

In prior work, we demonstrated the ability of a cell-free ethanol extract of Serratia marcescens Bizio N4-5 to provide suppression of damping-off of cucumber caused by $P$. ultimum. Suppression of damping-off by the N4-5 ethanol extract was equivalent to that provided by the seed treatment pesticide Thiram when experiments were performed in commercial potting mix (Roberts et al. 2007, 2014). We focused this work on seed treatment for control of damping-off because certain crops, such as cucumber, have a brief window of vulnerability to this disease (Hadar et al. 1983; Roberts et al. 1997). The rapid germination of sporangia of $P$. ultimum and subsequent seed colonization (Fukui et al. 1994; Nelson 1988; Windstam and Nelson 2008; Xi et al. 1995), coupled with this short window of vulnerability, limit the infection court in time and space, allowing inundation of the infection court with this ethanol extract at the time of seed treatment.

Here, we furthered our work with the N4-5 ethanol extract by (i) determining suppression of damping-off of cucumber caused by $P$. ultimum in two natural soils. It is important to test disease control in multiple soils because efficacy and consistency of performance of biologically based treatments can be strongly affected by varying abiotic (e.g., mineral concentrations, $\mathrm{pH}$, and oxygen tensions) and biotic (genetic structure of populations of target and nontarget pathogens and soil microbial community) factors in the soil (Handelsman and Stabb 1996; Roberts and Kobayashi 2011). We also (ii) determined the compatibility of this seed treatment with certain Trichoderma biological control fungi. An approach to overcoming inconsistent performance by biologically based treatments is the combination of multiple biologically based tactics (Lemanceau and Alabouvette 1991; Pierson and Weller 1994; Raupach and Kloepper 1998). The combination of this ethanol extract with Trichoderma biological control fungi may add additional mechanisms of disease suppression and 
may allow, through colonization of plant tissues or induction of plant defense response by the Trichoderma isolate, control of pathogens infecting regions of the plant distant from the seed treatment (Harman et al. 2004; Howell 2003).

\section{Materials and Methods}

Microbial isolates. Bacterial, fungal, and oomycete isolates used in this study (Table 1) were from the United States Department of Agriculture-Agricultural Research Service Sustainable Agricultural Systems Laboratory culture collection. Mycostop, containing the biological control agent Streptomyces griseoviridis strain K61, was used as a commercial product control.

Construction of Trichoderma harzianum Th23::hph-egfp. Trichoderma harzianum Rifai Th23 was tagged for this study with hygromycin B (Hyg) resistance using Agrobacterium tumefaciens (Smith and Townsend) Conn AGL-1 to deliver the binary vector SK1292:pBHt2-EGFP containing $h p h$ and $e g f p$. Transformation of isolate Th23 and the integration of $h p h$ and $e g f p$ into its genome were performed as described by Mullins et al. (2001), with modifications as per Lakshman et al. (2011). Briefly, microconidia $\left(1.0 \times 10^{8}\right.$ conidia/ml) from a 15-day-old Th 23 culture were mixed in equal portions with acetosyringone-induced $A$. tumefaciens AGL-1 cells and plated on a cellophane membrane (Bio-Rad, Hercules, CA) on cocultivation agar medium (Khang et al. 2006) containing $200 \mu \mathrm{M}$ acetosyringone. Following cocultivation, the membranes were transferred to potato dextrose agar (PDA) containing Hyg at $100 \mu \mathrm{g} / \mathrm{ml}, 200 \mu \mathrm{M}$ cefotaxime, and moxalactum at $100 \mu \mathrm{g} / \mathrm{ml}$. Hyg-resistant $\left(\mathrm{Hyg}^{\mathrm{R}}\right.$ ) colonies of isolate Th23 were observed following 7 to 9 days of incubation at 23 to $25^{\circ} \mathrm{C}$. Construction of the resultant strain, Th23::hph-egfp, was confirmed by growth on Hyg and by polymerase chain reaction (PCR). Isolate Th23::hph-egfp grew on PDA containing Hyg at $110 \mu \mathrm{g} / \mathrm{ml}$ whereas nontransformed colonies did not grow on PDA containing Hyg at $80 \mu \mathrm{g} / \mathrm{ml}$. For PCR, genomic DNA was purified from mycelia of Th23::hph-egfp and from Th23, as described by Lakshman et al. (2011), and used in PCR containing the $h p h$-specific primers HPH-F and HPH-R (Table 1) (Lakshman et al. 2011; Mullins et al. 2001). The PCR conditions were $94^{\circ} \mathrm{C}$ for $2 \mathrm{~min}$; 35 cycles of $94^{\circ} \mathrm{C}$ for $30 \mathrm{~s}, 60^{\circ} \mathrm{C}$ for $30 \mathrm{~s}$, and $72^{\circ} \mathrm{C}$ for $1 \mathrm{~min}$; and a final extension at $72^{\circ} \mathrm{C}$ for $5 \mathrm{~min}$. A specific band of $1 \mathrm{~kb}$ was observed from Th23::hph-egfp, as expected (Kemppainen et al. 2005). PCR was not performed for egfp in the respective transformed lines. The PCR product was agarose gel purified with the QIAquick Gel Extraction Kit (Qiagen Inc., Valencia, CA) and the DNA was sequenced using both the HPH-F and the HPH-R primers. The nucleotide sequence was compared with the National Center for Biotechnology Information database using the BLASTN search engine and found to be $100 \%$ homologous with a region of 815 nucleotides of the Neurospora cloning vector pTH1124.1 hph (AEJ38170). An amplicon of the expected size $(1 \mathrm{~kb})$ was not detected in PCR containing genomic DNA from Th23. Stability of strain Th23::hph-egfp was confirmed by five serial transfers on PDA in the absence of Hyg followed by plating on PDA containing Hyg at $110 \mu \mathrm{g} / \mathrm{ml}$. Hyg ${ }^{\mathrm{R}} \mathrm{Th} 23$ : hph-egfp cultures from single conidia were preserved in $25 \%$ glycerol at $-80^{\circ}$ C. T. virens (J. H. Mill., Giddens \& A. A. Foster) Arx GL-21 and Serratia marcescens strains N4-5 and N4-5R2 were also preserved in $25 \%$ glycerol at $-80^{\circ} \mathrm{C}$. P. ultimum Puzc was maintained on corn meal agar at room temperature.

Preparation of the N4-5 ethanol extract, Trichoderma sp. formulations, and treated seed. Ethanol extract was prepared from S. marcescens N4-5 grown on peptone glycerol agar plates at $28^{\circ} \mathrm{C}$, as described (Matsuyama et al. 1985; Roberts et al. 2007). Extract was dried under nitrogen and the residue was resuspended as indicated prior to use. Formulations of Trichoderma isolates were prepared on Biodac (Kadant Gran Tek, Inc., Green Bay, WI) in mycobags (Unicorm Imp. and Mfg. Corp., Commerce, TX), as described by Roberts et al. (2010). The Biodac granular formulation contained Trichoderma spp. at approximately $7.0 \log _{10} \mathrm{CFU} / \mathrm{g}$. For preparation of drenches for in-furrow application of Trichoderma spp., $50 \mathrm{~g}$ of Biodac formulation was suspended in $200 \mathrm{ml}$ of deionized water and ground with a tissue homogenizer (Ultra-Turrax T 25 basic; IKA-Werke, Staufen, Germany) prior to application. Controls were sterile Biodac in water.

For treatment of conventionally produced cucumber seed (Cucumis sativum 'Marketmore 76'), dried N4-5 ethanol extract was resuspended in $8 \mathrm{ml}$ of ethanol, incubated with seed for $30 \mathrm{~s}(8 \mathrm{ml}$ per $6.4 \mathrm{~g}$ of cucumber seed), and dried under a laminar flow hood. Controls were seed incubated in ethanol but no N4-5 ethanol extract. Live $S$. marcescens N4-5 or its rifampicin-resistant mutant, N4-5R2, was grown overnight in nutrient broth (NB), washed and resuspended in sterile distilled water (SDW), and applied to seed in a gelatin formulation, as described (Roberts et al. 2005). Biodac-formulated Trichoderma isolates were coated onto seed in the gelatin formulation (5 $\mathrm{g}$ of Biodac colonized by Trichoderma spp. or sterile noninoculated Biodac was added to $10 \mathrm{ml}$ of SDW and ground in a tissue mizer for $20 \mathrm{~s}$, and $2 \mathrm{ml}$ of this suspension mixed with $700 \mu \mathrm{l}$ of $12 \%$ gelatin [wt/vol] was applied to 140 cucumber seed). For the seed treatment containing both N4-5 ethanol extract and Trichoderma spp., the N4-5 ethanol extract was applied first as described above, the seed was dried under a laminar flow hood, and the Trichoderma isolate was applied to the seed in the gelatin formulation as described above. Seed treated with live-strain N4-5 contained approximately $8.0 \log _{10}$ CFU/seed while seed treated with Trichoderma isolates contained $5.0 \log _{10} \mathrm{CFU} / \mathrm{seed}$, as determined by dilution plating. Seed coated with gelatin plus SDW or sterile Biodac but no microbes were also used as controls.

In vitro inhibition of Trichoderma spp. with the N4-5 ethanol extract. For in vitro inhibition of mycelial growth of Trichoderma isolates, $10 \mu \mathrm{l}$ of N4-5 ethanol extract was spotted onto

Table 1. Microbial strains, plasmids, and primers

\begin{tabular}{|c|c|c|}
\hline Microbial isolate, plasmid, or primer & Relevant characteristics & Source, prior designation, or reference \\
\hline \multicolumn{3}{|l|}{ Bacterial isolate } \\
\hline Agrobacterium tumefaciens AGL-1 & Delivery strain for SK1292:pBHt2-EGFP & Chen et al. (2000) \\
\hline Serratia marcescens N4-5 & Produces prodigiosin; suppresses Pythium ultimum & $\begin{array}{l}\text { Kobayashi and El-Barrad (1996); Roberts } \\
\text { et al. (2007) }\end{array}$ \\
\hline S. marcescens $\mathrm{N} 4-5 \mathrm{R} 2$ & Spontaneous rifampicin-resistant mutant of strain N4-5 & Roberts et al. (2007) \\
\hline \multicolumn{3}{|l|}{ Fungal or oomycete isolate } \\
\hline Pythium ultimum Puzc & Pathogenic on cucumber & Roberts et al. $(2005,2007)$ \\
\hline Trichoderma virens GL21 & Suppresses $P$. ultimum & Roberts et al. (2005) \\
\hline T. harzianum Th23 & Biological control fungus & ATCC MYA-647; Roberts et al. (2010) \\
\hline T. harzianum Th23::hph-egfp & Isolate Th23 containing the $h p h$-egfp cassette & This study \\
\hline \multicolumn{3}{|l|}{ Plasmid } \\
\hline SK1292:pBHt2-EGFP & Binary vector; contains $h p h$ and $e g f p$ & Mosquera et al. (2009) \\
\hline \multicolumn{3}{|c|}{ or } \\
\hline HPH-F & 5'-AAGCCTGAACTCACCGCGAC-3' & Kemppainen et al. (2005) \\
\hline HPH-R & 5'-CTATTCCTTTGCCC TCGGAC $3^{\prime}$ & $\ldots$ \\
\hline
\end{tabular}


10-mm-diameter sterile filter disks (Whatman number 1) located at the periphery of PDA agar plates, and a single 13-mm-diameter plug of Trichoderma spp. was added to the center of the petri dish. Filter disks spotted with $75 \mu \mathrm{l}$ of ethanol were used as controls. Petri dishes were incubated at room temperature and zones of inhibition around the filter disks were measured. Experiments were run at least two times with four replicates per treatment for $72 \mathrm{~h}$. Data from experiments were combined prior to determining mean millimeter zone of inhibition with standard deviation $(n=2)$.

In vitro colonization of cucumber seedlings by Trichoderma isolates. Seed treated as described above, or Marketmore 76 cucumber commercially treated with Thiram, were placed at the periphery of PDA agar plates, a single 13-mm-diameter plug of Trichoderma spp. was added to the center of the petri dish, the plates were incubated for 11 days at $28^{\circ} \mathrm{C}$, and the seed coat and developing root system were rated for colonization microscopically. For experiments with isolate Th23::hph-egfp, PDA contained Hyg at $100 \mu \mathrm{g} / \mathrm{ml}$. Microscopy was performed using an Olympus SZX12 stereoscope using a dark-field DF PLFL 2X PF lens (Olympus Corp., Center Valley, PA) on the $\times 0.7$ setting. A binary scoring scheme was used to distinguish seed coats and root tissues colonized and not colonized by the Trichoderma isolates ( 1 and 0 , respectively). Experiments were performed at least twice, with four replicates per treatment. Representative images of treatments were obtained using a Hirox KH-7700 digital microscope (Hirox-USA, Inc., Hackensack, NJ) with an MX-macro lens.

In situ cucumber colonization experiments. Formulations and cucumber seed treatments were prepared for in situ rhizosphere colonization experiments as above. Treatments in the first set of experiments were (i) seed treated with isolate Th23::hph-egfp, (ii) seed treated with Th23::hph-egfp and N4-5 ethanol extract, (iii) seed treated with Th23::hph-egfp and live S. marcescens N4-5 or N4-5R2, (iv) seed treated with sterile Biodac, (v) seed treated with N4-5 ethanol extract only, (vi) seed treated with live N4-5 or N4-5R2, (vii) Th23::hph-egfp formulation applied in-furrow (1 $\mathrm{g}$ of Th23::hph-egfp formulation applied to the planting medium near the seed in $1 \mathrm{ml}$ of aqueous suspension), (viii) Th23::hph-egfp formulation applied in-furrow plus seed treated with N4-5 ethanol extract, (ix) Th23:: $h p h$-egfp formulation applied in-furrow plus seed treated with live N4-5 or N4-5 R2, and (x) $1 \mathrm{~g}$ of sterile Biodac applied in-furrow. Treatments in the second set of experiments were (i) Th23::hph-egfp formulation applied in-furrow plus nontreated seed, (ii) Th23::hph-egfp formulation applied in-furrow plus seed treated with N4-5 ethanol extract, (iii) Th23::hph-egfp formulation applied in-furrow plus seed treated with Thiram, (iv) sterile Biodac applied in-furrow plus nontreated seed, (v) sterile Biodac applied in-furrow plus seed treated with N4-5 ethanol extract, and (vi) sterile Biodac applied infurrow plus seed treated with Thiram. Treatments were applied to $45 \mathrm{ml}$ of potting mix (Pro-Mix PGX; Premier Horticulture, Inc., Quakertown, PA) in 50-ml sterile conical tubes and tubes incubated at $22^{\circ} \mathrm{C}$ with a $12-\mathrm{h}$ photoperiod in the growth chamber. Populations of Th23::hph-egfp, N4-5, or N4-5R2 were determined periodically by dilution plating onto PDA containing Hyg at $100 \mu \mathrm{g} / \mathrm{ml}$, NB agar, and NB agar containing rifampicin at $100 \mu \mathrm{g} / \mathrm{ml}$, respectively. Each set of experiments was performed at least twice, with six replicates per treatment arranged in a completely randomized design. Mean $\log _{10}$ Th23::hph-egfp-like CFU per entire cucumber rhizosphere was determined for each treatment and subjected to analysis of variance (ANOVA), and differences among means were estimated using a least significant difference (LSD) test protected against type I experimental error (SAS Institute, Cary, NC). Mean $\log _{10}$ CFU N4-5-like colonies in the entire cucumber rhizosphere was also determined with standard deviation in treatments where N4-5 was applied. Experiments were analyzed independently $(n=6)$ because sampling dates varied between the two experiments.

Suppression of damping-off of cucumber caused by $\boldsymbol{P}$. ultimum. Experiments to determine suppression of damping-off of cucumber caused by $P$. ultimum were performed essentially as described (Roberts et al. 2005, 2007) with conventionally produced cucumber seed us-


$4.8 \%$ organic matter), or natural soil number 15 (loam soil, $\mathrm{pH} 5.1$,
$1.4 \%$ organic matter) as the planting medium. Formulations and cucumber seed treatments were prepared as described above. Treatments applied are stated in Tables 2 through 5. The Biodac granular formulation used in these experiments contained Trichoderma spp. at approximately $7.0 \log _{10} \mathrm{CFU} / \mathrm{g}$, with $1 \mathrm{~g}$ being applied to the region near each seed, while seed treated with Trichoderma spp. contained Trichoderma spp. at approximately $5.0 \log _{10} \mathrm{CFU} / \mathrm{seed}$. Seed treated with live N4-5 contained N4-5 at approximately 7.0 $\log _{10} \mathrm{CFU} / \mathrm{seed}$.

To produce sporangia, $P$. ultimum was grown at $25^{\circ} \mathrm{C}$ for 3 days, flooded with sterile soil extract (Ayers and Lumsden 1975), and incubated at $25^{\circ} \mathrm{C}$ for 7 to 28 days. Sporangia from these plates were washed and incorporated into potting mix (Pro-Mix PGX). Potting mix, potting mix amended with sporangia of $P$. ultimum or with SDW, treated seed or nontreated seed, and potting mix amended with sporangia of $P$. ultimum or SDW were added as sequential layers to 6-cm-diameter cups, as described by Roberts et al. (1997). In experiments containing natural soil numbers 11 or 15 , potting mix, natural soil amended with sporangia of $P$. ultimum or with SDW, treated seed or nontreated seed, and natural soil amended with sporangia of $P$. ultimum or SDW were added as sequential layers to the 6-cmdiameter cups. For each treatment, eight replicate cups were sown with 5 seeds each and incubated in a growth chamber at $22^{\circ} \mathrm{C}$ for 14 days with a 12 -h photoperiod. Treatments were arranged in a completely randomized design. Mean plant stand per cup for each treatment was determined and subjected to ANOVA, and differences among means estimated using LSD (SAS Institute). Experiments were performed at least two times and analyzed independently only if there was a significant experiment-treatment effect $(P \leq 0.05)$.

\section{Results}

In vitro inhibition of Trichoderma spp. with the N4-5 ethanol extract. The N4-5 ethanol extract from $S$. marcescens N4-5 inhibited mycelial growth by $T$. harzianum Th23::hph-egfp growing on PDA. Mean zone of inhibition was $1.5 \pm 0.3 \mathrm{~mm}$ in data combined from two experiments. The N4-5 ethanol extract did not result in zones of inhibition of mycelial growth $(0.0 \pm 0.0 \mathrm{~mm})$ when tested against $T$. virens isolate GL21 in either of two experiments. However, this extract may have been slightly inhibitory to isolate GL21 because mycelial growth around the trailing edge of the filter paper containing the N4-5 ethanol extract was slower than with the ethanol-only control. There was no inhibition of mycelial growth $(0.0 \pm 0.0 \mathrm{~mm})$ by the ethanol-only control in any experiment.

In vitro colonization of cucumber seedlings by Trichoderma spp. after seed treatment. Experiments were performed where seedlings were analyzed for surface colonization by Trichoderma isolates after seed was coated with various seed treatments. For these experiments, treated seed and plugs of Trichoderma spp. were placed on PDA and incubated for 11 days at $28^{\circ} \mathrm{C}$, and colonization of the seed coat and developing root by Trichoderma spp. was determined microscopically. Isolate Th23::hph-egfp consistently colonized the cucumber seed coat $(100 \%)$ and emerging root system $(\geq 94 \%)$ of almost all the treatments (no seed treatment, N4-5 ethanol extract, ethanol only, and gelatin). The exception was for seed treated with Thiram, where Th23::hph-egfp was detected on only $75 \%$ of the seed coats but $100 \%$ of the roots.

Microscopic analyses of the extent of Th23::hph-egfp colonization on different seed treatments showed that the N4-5 ethanol extracttreated seed was colonized more extensively than Thiram-treated seed (Fig. 1A and B). However, colonization of N4-5 ethanol extract- and Thiram-treated seed coats was less extensive than the respective ethanol-only and nontreated controls (Fig. 1A and B). Isolate Th23::hph-egfp colonized the Thiram-treated seed coat sparingly but was capable of colonizing the emerging seedling (Fig. 1D) in $88 \%$ of the replicates. Colonization of cucumber by Th23::hph-egfp was inhibited by the live N4-5 seed treatment, with Th23::hph-egfp being detected on 19\% of the seed coats and $75 \%$ of the roots. This treatment also appeared to inhibit seed germination, with only $25 \%$ of the seed germinating. However, different results may be obtained in situ, where nutrients for growth by N4-5 would 
not be as prevalent; the PDA supported substantial growth by strain N4-5 (Fig. 1C).

Isolate GL-21 also colonized, at least to some extent, seed that was not treated and treated with the N4-5 ethanol extract, the ethanol-only control, and Thiram. In two experiments, each with four replicates per treatment, GL-21 was detected on $100 \%$ of the seed coats and $100 \%$ of the roots from almost all of the treatments (no seed treatment, N4-5 ethanol extract, ethanol-only control, and Thiram). There was no evidence of GL-21 on cucumber seed coats in any of the eight replicates or the one emerging root when seed were treated with the live N4-5 treatment. Unlike isolate Th23::hph-egfp, GL-21 was not consistently detected on seed coated with gelatin, the coating used to apply live cells of strain N4-5. GL-21 was detected on $25 \%$ of the seed coats and $0 \%$ of the roots from seed treated with gelatin. There was no evidence of colonization of cucumber in controls where no Trichoderma sp. was added to the petri dish.

In situ colonization of cucumber rhizosphere by $T$. harzianum Th23::hph-egfp when applied with cucumber seed treatments containing live strain N4-5, N4-5 ethanol extract, or Thiram. Initial experiments were conducted to determine colonization of the entire cucumber rhizosphere by isolate Th23::hph-egfp when this beneficial fungus was applied as a seed treatment in combination with seed treatments containing live strain N4-5 or ethanol extract of this bacterium (Supplementary Table S1). There was no evidence of inhibition of colonization of Th23::hph-egfp by treatments containing live strain N4-5 or N4-5 ethanol extract when this fungus was applied as a seed treatment, even with the N4-5 ethanol extract seed treatment containing concentrated extracellular compounds from strain N4-5. Similar populations of T. harzianum Th23:: hph-egfp were detected in cucumber rhizosphere at the end of both 3 -week experiments among the treatments containing Th23::hph-egfp applied to the nontreated seed control, Th23::hph-egfp plus N4-5 ethanol extract applied to the seed, and Th23::hph-egfp plus live N4-5 applied to the seed. Populations of Th23::hph-egfp were similar in all treatments in the first experiment at days 7, 14, and 24 and were in the range of $5.0 \log _{10} \mathrm{CFU} /$ rhizosphere to $4.0 \log _{10} \mathrm{CFU} /$ rhizosphere. Populations of Th23::hph-egfp were similar at 0,10 , and 25 days in a second experiment for treatments where Th23::hph-egfp was applied as a seed treatment.

Initial experiments were also conducted to determine colonization of the entire cucumber rhizosphere by isolate Th23::hph-egfp when this beneficial fungus was applied in-furrow as a drench to the seed area in combination with seed treatments containing live strain N4-5 or ethanol extract of this bacterium. Similar populations of T. harzianum Th23::hph-egfp were detected in cucumber rhizosphere at the end of both 3-week experiments among the treatments containing Th23::hph-egfp applied in-furrow plus the nontreated seed, Th23:: hph-egfp applied in-furrow plus N4-5 ethanol extract treated-seed, and Th23::hph-egfp applied in-furrow plus live N4-5 applied to the seed. Populations of Th23::hph-egfp ranged from approximately $7.0 \log _{10} \mathrm{CFU} /$ rhizosphere at day 0 to $4.5 \log _{10} \mathrm{CFU} /$ rhizosphere at day 24 in the two experiments. Background Th23::hph-egfp-like colonies were detected in the sterile Biodac controls at certain sampling times in the above experiments. However, populations of Th23::hph-egfp-like fungi were typically much lower in these controls than in treatments where Th23::hph-egfp was applied.

Substantial populations of N4-5 were present throughout both experiments in treatments where live cells of strain N4-5 were applied. Similar populations of strain N4-5 were detected in these experiments as were detected in a pilot experiment where the rifampicinresistant mutant N4-5R2 was used and with rifampicin-containing selective medium. There was no apparent impact of the concentration of extracellular compounds in the N4-5 ethanol extract seed treatment or the application of live N4-5 to the seed because populations
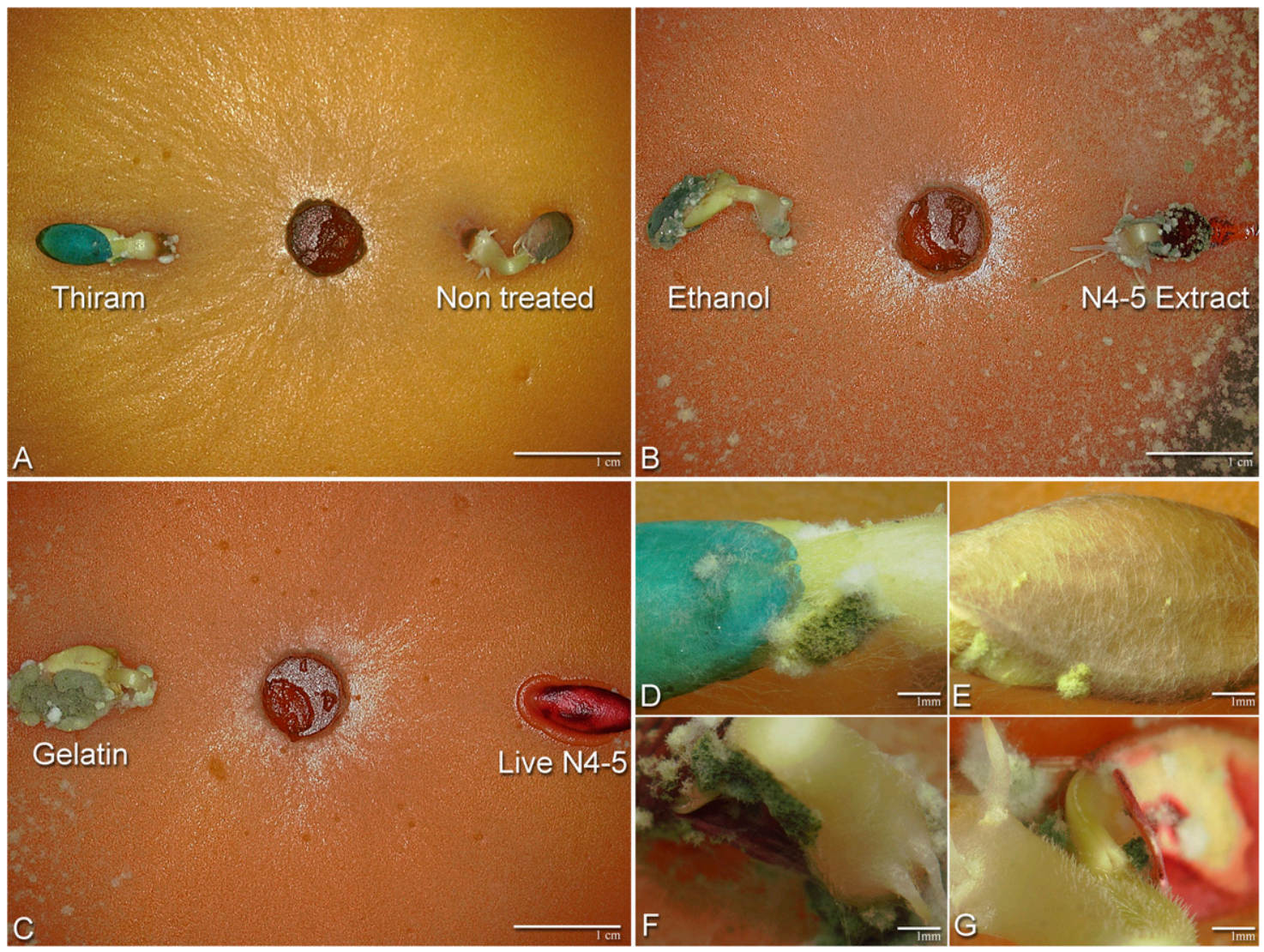

Fig. 1. In vitro colonization of cucumber by Trichoderma harzianum Th23::hph-egfp after various seed treatments. A, Thiram and nontreated seed; B, seed treated with ethanol and Serratia marcescens N4-5 ethanol extract; C, seed treated with gelatin and live-N4-5. Higher magnification images of colonization by Th23::hph-egfp of seed treated with D, Thiram; E, nothing; F, N4-5 ethanol extract; and G, live N4-5. See Materials and Methods for more details regarding seed treatments and experimental design. Colonization of plant tissue is indicated by yellow hyphae or green spore structures. 
of Th23::hph-egfp were similar in these treatments to populations of Th23::hph-egfp in the nontreated control, when this fungus was applied in-furrow or as a seed treatment.

A second set of experiments was conducted where colonization of cucumber rhizosphere by isolate Th23::hph-egfp was determined when this beneficial fungus was applied in-furrow as a drench to the seed area in combination with seed treatments containing Thiram, N4-5 ethanol extract, or the nontreated seed control (Fig. 2). T. harzianum Th23::hph-egfp was only applied in-furrow as a drench in these experiments because seed treatment application of this fungus delivered substantially lower populations of this fungus (see experiments above). There was no evidence of inhibition of colonization of Th23::hph-egfp by seed treatment with the N4-5 ethanol extract or Thiram in this second set of experiments. Essentially similar populations of $T$. harzianum Th23::hph-egfp were detected in cucumber rhizosphere over both 3-week experiments among all three of these treatments. No Th23::hph-egfp-like colonies were detected in control treatments where this fungus was not applied.

Suppression of damping-off of cucumber in potting mix with Trichoderma spp. and the N4-5 ethanol extract. Experiments were conducted to compare suppression of $P$. ultimum damping-off

\section{A}

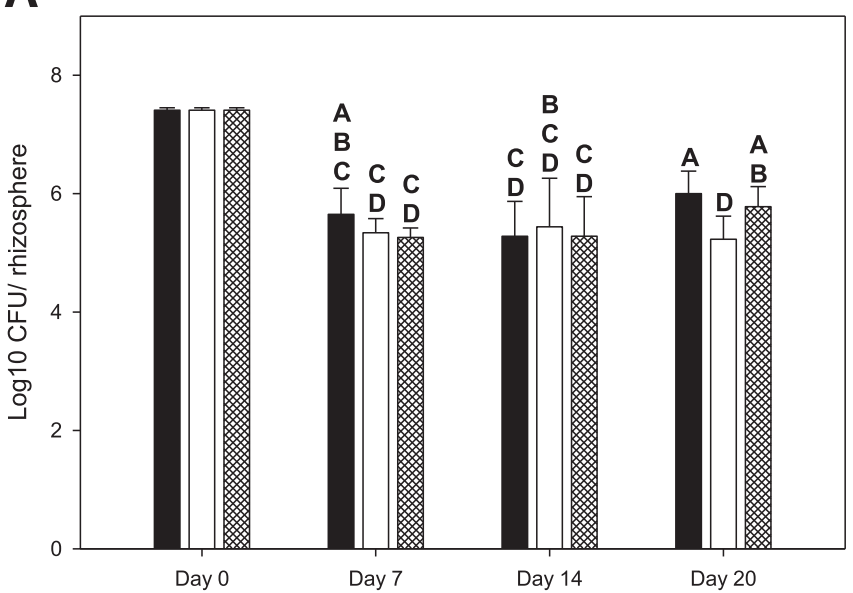

B



Fig. 2. Colonization of cucumber rhizosphere by Trichoderma harzianum Th23:: hph-egfp when applied as an in-furrow drench to the seed area in association with seed treated with N4-5 ethanol extract (solid bar) or Thiram (open bar), or nontreated seed (hatched bar). A, Experiment 1 and B, experiment 2. For mean $\log _{10}$ CFU/rhizosphere, treatment values are the mean of a single experiment containing six replicates for each treatment $(n=6)$. Means were separated by least significant difference (LSD) with LSD in experiment $1=0.3963$ and LSD in experiment $2=0.2951$. Bars with the same letter in the same subfigure are not significantly different $(P \leq 0.05)$. The control treatments sterile Biodac applied in-furrow in association with seed treated with N4-5 ethanol or Thiram, or nontreated cucumber seed were also run but are not shown. There were no Th23::hph-egfp-like colonies detected in any replicates from any of these controls. provided by seed treatments containing the N4-5 ethanol extract, seed treatment or in-furrow application of T. harzianum Th23:: hph-egfp, and combinations of treatments containing the N4-5 ethanol extract with seed treatment or in-furrow application of $T$. harzianum Th23::hph-egfp (Table 2). There was no reduction in disease control when these treatment components were combined. In fact, the combination of the N4-5 ethanol extract seed treatment with in-furrow application of $T$. harzianum Th23::hph-egfp provided disease control at both levels of inoculum of $P$. ultimum that was similar to the healthy check. The treatment containing seed treated with the N4-5 ethanol extract alone provided disease suppression at both levels of inoculum but plant stand with this treatment was not similar to the healthy check. The treatment containing in-furrow application of T. harzianum Th23::hph-egfp alone provided disease control at the low level of pathogen inoculum whereas seed treatment application of this fungus alone did not provide disease control at either level of pathogen inoculum. In similar experiments conducted with $T$. virens GL-21, the treatment containing the combination of the N4-5 ethanol extract seed treatment with infurrow application of $T$. virens GL-21 also provided disease control at both levels of pathogen inoculum in both experiments (Table 3 ). However, the N4-5 ethanol extract seed treatment performed better in this set of experiments and was similar to the healthy check at both levels of pathogen inoculum in both experiments.

In-furrow application of the Trichoderma isolates typically resulted in better disease control than seed treatment application of these fungi (Tables 2 and 3). In-furrow application of Trichoderma spp. provided Trichoderma spp. at approximately $7.0 \log _{10} \mathrm{CFU} / \mathrm{g}$ (approximately $7.0 \log _{10}$ CFU near each seed) while seed treatments applications with these fungi provided Trichoderma spp. at approximately $5.0 \log _{10} \mathrm{CFU} / \mathrm{seed}$. There was no evidence of phytotoxicity with treatments containing the N4-5 ethanol extract or Trichoderma spp. preparations. However, the Biodac formulation appeared to enhance disease caused by $P$. ultimum in some experiments (Tables 2 and 3 ).

Table 2. Suppression of damping-off of cucumber caused by Pythium ultimum in potting mix with Trichoderma harzianum Th23::hph-egfp combined with ethanol cell extract from Serratia marcescens N4-5

\begin{tabular}{|c|c|c|c|}
\hline \multirow[b]{2}{*}{ Treatment $^{\mathrm{z}}$} & \multicolumn{3}{|c|}{$\begin{array}{l}\text { Mean plant stand per pot } \\
\text { at different } P \text {. ultimum } \\
\text { infestation levels }{ }^{y}\end{array}$} \\
\hline & $\mathbf{0}$ & 10 & 60 \\
\hline No treatment & $4.69 \mathrm{ABC}$ & $1.63 \mathrm{G}$ & $0.75 \mathrm{GHI}$ \\
\hline N4-5 ethanol extract on seed & $4.88 \mathrm{AB}$ & $3.63 \mathrm{DEF}$ & $3.81 \mathrm{CDE}$ \\
\hline Th23::hph-egfp on seed & $4.56 \mathrm{ABC}$ & $0.50 \mathrm{IJ}$ & $0.44 \mathrm{IJ}$ \\
\hline $\begin{array}{l}\text { N4-5 ethanol extract }+ \\
\text { Th23::hph-egfp on seed }\end{array}$ & $4.63 \mathrm{ABC}$ & 4.25 A-D & $2.88 \mathrm{~F}$ \\
\hline Th23::hph-egfp in-furrow & 4.69 $\mathrm{ABC}$ & $3.06 \mathrm{EF}$ & $1.13 \mathrm{GH}$ \\
\hline $\begin{array}{l}\text { Th23::hph-egfp in-furrow }+ \\
\text { N4-5 ethanol extract on seed }\end{array}$ & $5.00 \mathrm{~A}$ & 4.25 A-D & $4.13 \mathrm{~A}-\mathrm{D}$ \\
\hline Ethanol on seed only & 4.56 $\mathrm{ABC}$ & $2.75 \mathrm{~F}$ & $1.44 \mathrm{GH}$ \\
\hline Gelatin + sterile Biodac on seed & 4.69 $\mathrm{ABC}$ & 0.69 HIJ & $0.00 \mathrm{~J}$ \\
\hline $\begin{array}{l}\text { Ethanol }+ \text { Gelatin }+ \text { sterile } \\
\text { Biodac on seed }\end{array}$ & $4.63 \mathrm{ABC}$ & $0.25 \mathrm{IJ}$ & $0.06 \mathrm{~J}$ \\
\hline Sterile Biodac in-furrow & 4.00 BCD & 0.69 HIJ & $0.50 \mathrm{IJ}$ \\
\hline $\begin{array}{l}\text { Sterile Biodac in-furrow + } \\
\text { ethanol on seed }\end{array}$ & $3.63 \mathrm{DEF}$ & $0.56 \mathrm{HIJ}$ & $0.25 \mathrm{IJ}$ \\
\hline
\end{tabular}

$\mathrm{y}$ Values are the mean of two experiments $(n=2)$ expressed as mean plant stand per pot. Results were combined prior to analysis because there was no significant experiment-treatment effect $(P=0.3011)$. Treatments in both experiments contained eight replicate pots, each containing 5 seeds. Numbers followed by the same letter are not significantly different $(P \leq 0.05)$ as determined by a protected least significant difference test. Least significant difference was 0.89. P. ultimum was added at 0,10 , and 60 sporangia $/ \mathrm{cm}^{3}$ of potting mix inoculum.

z See Materials and Methods for a description of treatments. No treatment indicates that cucumber seed were not treated prior to being sown and there were no in-furrow applications. Seed treatment with Th23::hph-egfp resulted in approximately $10^{5}$ hygromycin-resistant, Trichoderma-like CFU per seed while in-furrow application delivered approximately $10^{7}$ hygromycinresistant, Trichoderma-like CFU to the seed region. 
Suppression of damping-off of cucumber in two natural soils with Trichoderma spp. and the N4-5 ethanol extract. An inoculum sandwich technique was used to test the N4-5 ethanol extract and other treatments for suppression of damping-off in natural soil numbers 11 and 15 . For this, treatments and seed were sandwiched between layers of natural soil containing sporangia of $P$. ultimum which were, in turn, on top of a layer of potting mix. Due to the rapidity with which $P$. ultimum infects germinating seed and the short window of vulnerability of cucumber to damping-off caused by P. ultimum, the disease interaction should occur within the small spatial area within the natural soil (Roberts et al. 1997).

In natural soil number 11, a sandy loam soil, the N4-5 ethanol extract applied as a seed treatment was very effective. This treatment resulted in a plant stand that was significantly greater $(P \geq 0.05)$ than that associated with the nontreated (pathogen) control at both levels of pathogen inoculum and similar to the healthy check at the low level of pathogen inoculum (Table 4). In addition, disease suppression with the N4-5 ethanol extract seed treatment was similar to the seed treatment pesticide Thiram at both levels of pathogen inoculum. The N4-5 ethanol extract seed treatment was generally superior to individual in-furrow applications of Th23::hph-egfp and GL-21 and the commercial biological control product Mycostop, containing Streptomyces griseoviridis strain K61. The N4-5 ethanol extract seed treatment was also compatible with these biological control agents when they were applied in combination. Application of Th23::hph-egfp, GL-21, or Mycostop in combination with seed treatment with the N4-5 extract did not result in diminished disease suppression in any case by the combination treatments (Table 4). However, disease pressure with soil number 11 was not great enough to critically evaluate combination treatments for improved disease suppression over the components applied individually. It appeared that nontarget pathogens that may have been present in the natural soil did not affect plant stand because the healthy check stand was unaffected.

Seed treatment with the N4-5 ethanol extract was not as effective in natural soil number 15 , a loam soil (Table 5). Plant stand associated with this treatment was significantly greater $(P \geq 0.05)$ than the nontreated (pathogen) control only in experiment 1 at the low level of pathogen inoculum and in experiment 3 at the high level of pathogen inoculum. In addition, plant stand associated with the N4-5 ethanol extract seed treatment was significantly lower than the healthy check in all three experiments at the highest level of $P$. ultimum inoculum. The Thiram seed treatment did not perform well in soil number 15 either. Disease suppression provided by the
N4-5 ethanol extract seed treatment was generally not as effective as that associated with the Thiram seed treatment, with plant stand being significantly lower than the Thiram treatment at the low pathogen inoculum level in both experiments 2 and 3 (Table 5). The N4-5 ethanol extract was generally superior to in-furrow applications of

Table 4. Suppression of damping-off of cucumber in natural soil number 11 with in-furrow applications of Trichoderma harzianum Th23::hph-egfp, T. virens GL-21, or ethanol extract of Serratia marcescens N4-5 applied alone and in combination ${ }^{\mathrm{x}}$

\begin{tabular}{llll}
\hline & \multicolumn{3}{c}{$\begin{array}{c}\text { Mean plant stand per pot at } \\
\text { different } \boldsymbol{P} \text {. ultimum } \\
\text { infestation levels }\end{array}$} \\
\cline { 2 - 4 } Treatment & \multicolumn{1}{c}{$\mathbf{0}$} & $\mathbf{2 0}$ & $\mathbf{8 0}$ \\
\hline No treatment & $4.67 \mathrm{AB}$ & $1.38 \mathrm{FGH}$ & $0.41 \mathrm{I}$ \\
N4-5 ethanol extract & $4.58 \mathrm{AB}$ & $4.50 \mathrm{ABC}$ & $3.91 \mathrm{CD}$ \\
N4-5 ethanol extract + Th23::hph-egfp & $4.63 \mathrm{AB}$ & $4.42 \mathrm{ABC}$ & $4.18 \mathrm{ABC}$ \\
N4-5 ethanol extract + GL-21 & $4.75 \mathrm{~A}$ & $4.19 \mathrm{ABC}$ & $4.06 \mathrm{BC}$ \\
N4-5 ethanol extract + Mycostop & $4.58 \mathrm{AB}$ & $4.25 \mathrm{ABC}$ & $4.33 \mathrm{ABC}$ \\
Th23::hph-egfp & $4.63 \mathrm{AB}$ & $2.67 \mathrm{E}$ & $0.92 \mathrm{GHI}$ \\
GL-21 & $4.69 \mathrm{AB}$ & $3.38 \mathrm{D}$ & $3.38 \mathrm{D}$ \\
Mycostop & $4.38 \mathrm{ABC}$ & $1.71 \mathrm{~F}$ & $0.71 \mathrm{I}$ \\
Thiram & $4.80 \mathrm{~A}$ & $4.33 \mathrm{ABC}$ & $4.50 \mathrm{ABC}$ \\
Ethanol only & $4.54 \mathrm{ABC}$ & $1.63 \mathrm{~F}$ & $0.83 \mathrm{HI}$ \\
Sterile Biodac & $4.71 \mathrm{AB}$ & $1.50 \mathrm{FG}$ & $0.83 \mathrm{HI}$ \\
Ethanol + sterile Biodac & $4.38 \mathrm{ABC}$ & $1.67 \mathrm{~F}$ & $0.33 \mathrm{I}$ \\
\hline
\end{tabular}

${ }^{\mathrm{x}}$ Inoculum was applied in soil number 11 (sandy loam, $\mathrm{pH} 5.1,4.8 \%$ organic matter) using an inoculum sandwich technique, where treatments and seed were sandwiched between layers of natural soil number 11 containing sporangia of $P$. ultimum which were, in turn, on top of a layer of potting mix. Trichoderma isolates were applied in-furrow as a drench to the seed area. In-furrow application delivered approximately $10^{7}$ hygromycinresistant, Trichoderma-like CFU to the seed region. The N4-5 ethanol extract was applied as a seed treatment.

y $P$. ultimum was added at 0,20 , and 80 sporangia/ $/ \mathrm{cm}^{3}$ of soil inoculum. Values are the mean of three experiments $(n=3)$, with eight treatment replicates, each containing 5 seeds, expressed as mean plant stand per pot. Numbers followed by the same letter are not significantly different $(P \leq$ 0.05 ) for that experiment as determined by a protected least significant difference test. Least significant difference was 0.6498. Data from experiments were combined because there was no significant experiment-treatment effect $(P=0.0779)$

${ }^{z}$ See Materials and Methods for a complete description of treatments. No treatment indicates that cucumber seed were not treated prior to being sown and there were no in-furrow applications.

Table 3. Suppression of damping-off of cucumber caused by Pythium ultimum in potting mix with Trichoderma virens GL-21 combined with ethanol extract of Serratia marcescens $\mathrm{N} 4-5$

\begin{tabular}{|c|c|c|c|c|c|c|}
\hline \multirow[b]{3}{*}{ Treatment $^{\mathrm{z}}$} & \multicolumn{6}{|c|}{ Mean plant stand per pot at different $P$. ultimum infestation levels ${ }^{y}$} \\
\hline & \multicolumn{3}{|c|}{ Experiment 1} & \multicolumn{3}{|c|}{ Experiment 2} \\
\hline & $\mathbf{0}$ & 10 & 60 & $\mathbf{0}$ & 10 & 60 \\
\hline No treatment & $5.00 \mathrm{~A}$ & $3.13 \mathrm{C}-\mathrm{F}$ & $1.75 \mathrm{G}-\mathrm{K}$ & $5.00 \mathrm{~A}$ & $3.75 \mathrm{~A}-\mathrm{D}$ & $2.13 \mathrm{E}-\mathrm{J}$ \\
\hline N4-5 ethanol extract on seed & $5.00 \mathrm{~A}$ & $4.25 \mathrm{ABC}$ & $3.75 \mathrm{~A}-\mathrm{D}$ & $5.00 \mathrm{~A}$ & $5.00 \mathrm{~A}$ & 4.00 ABC \\
\hline GL21 on seed & $5.00 \mathrm{~A}$ & $2.50 \mathrm{D}-\mathrm{H}$ & $1.13 \mathrm{I}-\mathrm{L}$ & $5.00 \mathrm{~A}$ & $3.75 \mathrm{~A}-\mathrm{D}$ & $1.50 \mathrm{G}-\mathrm{K}$ \\
\hline N4-5 ethanol extract + GL21 on seed & $5.00 \mathrm{~A}$ & 3.63 B-E & $3.38 \mathrm{CDE}$ & $4.38 \mathrm{AB}$ & $4.25 \mathrm{AB}$ & $4.63 \mathrm{~A}$ \\
\hline GL21 in-furrow & $5.00 \mathrm{~A}$ & $2.38 \mathrm{E}-\mathrm{I}$ & $1.88 \mathrm{~F}-\mathrm{J}$ & $4.88 \mathrm{~A}$ & $4.38 \mathrm{AB}$ & $2.88 \mathrm{C}-\mathrm{F}$ \\
\hline $\begin{array}{l}\text { GL21 in-furrow + N4-5 ethanol extract } \\
\text { on seed }\end{array}$ & $4.86 \mathrm{AB}$ & $5.00 \mathrm{~A}$ & $5.00 \mathrm{~A}$ & $5.00 \mathrm{~A}$ & $4.50 \mathrm{~A}$ & $4.88 \mathrm{~A}$ \\
\hline Ethanol on seed only & $5.00 \mathrm{~A}$ & $2.88 \mathrm{D}-\mathrm{G}$ & $1.38 \mathrm{H}-\mathrm{L}$ & $5.00 \mathrm{~A}$ & $2.50 \mathrm{D}-\mathrm{I}$ & $1.13 \mathrm{JK}$ \\
\hline Gelatin + sterile Biodac on seed & $5.00 \mathrm{~A}$ & $1.13 \mathrm{I}-\mathrm{L}$ & $0.13 \mathrm{~L}$ & $5.00 \mathrm{~A}$ & $2.75 \mathrm{C}-\mathrm{G}$ & $0.38 \mathrm{~K}$ \\
\hline Ethanol + Gelatin + sterile Biodac on seed & $5.00 \mathrm{~A}$ & $0.50 \mathrm{KL}$ & $0.25 \mathrm{~L}$ & $4.88 \mathrm{~A}$ & $3.13 \mathrm{~B}-\mathrm{E}$ & $1.25 \mathrm{IJK}$ \\
\hline Sterile Biodac in-furrow & $4.88 \mathrm{AB}$ & $0.50 \mathrm{KL}$ & $0.88 \mathrm{JKL}$ & $1.75 \mathrm{~F}-\mathrm{J}$ & $2.63 \mathrm{D}-\mathrm{H}$ & $1.88 \mathrm{E}-\mathrm{J}$ \\
\hline Sterile Biodac in-furrow + ethanol on seed & $5.00 \mathrm{~A}$ & $1.63 \mathrm{G}-\mathrm{K}$ & $1.00 \mathrm{JKL}$ & $1.38 \mathrm{H}-\mathrm{K}$ & $2.50 \mathrm{D}-\mathrm{I}$ & $1.63 \mathrm{~F}-\mathrm{K}$ \\
\hline
\end{tabular}

$\mathrm{y}$ Values are the mean of eight replicates, each containing 5 seeds, expressed as mean plant stand per pot. Numbers followed by the same letter are not significantly different $(P \leq 0.05)$ for that experiment as determined by a protected least significant difference test. Least significant difference was 1.30 for experiment 1 and 1.27 for experiment 2. Data from both experiments could not be combined because there was a significant experiment-treatment effect $(P<0.0001)$. $P$. ultimum was added at 0,10 , and 60 sporangia/ $/ \mathrm{cm}^{3}$ of potting mix inoculum.

${ }^{\mathrm{z}}$ See Materials and Methods for a description of treatments. No treatment indicates that cucumber seed were not treated prior to being sown and there were no infurrow applications. Seed treatment with Gl-21 resulted in approximately $10^{5}$ hygromycin-resistant, Trichoderma-like CFU per seed while in-furrow application of GL-21 delivered approximately $10^{7}$ hygromycin-resistant, Trichoderma-like CFU to the seed region. 
the biological control agents Th23::hph-egfp and Mycostop when these biological control agents were applied individually in soil number 15. Plant stand associated with in-furrow application of $T$. virens GL-21 was similar to that of the N4-5 ethanol extract in all cases, with the exception of the high level of inoculum in experiment 2. It appeared that nontarget pathogens that may have been present in the natural soil did not affect plant stand because the healthy check stand was unaffected.

The N4-5 ethanol extract seed treatment was compatible with these biological control agents in soil number 15 when they were applied in combination. Application of Th23::hph-egfp, GL-21, or Mycostop in combination with seed treatment with the N4-5 ethanol extract did not result in diminished disease suppression in any case relative to individual application of the components of these combined treatments (Table 5). Combining treatments improved disease control in some situations. Application of Th23::hph-egfp or Mycostop in combination with seed treatment with the N4-5 ethanol extract improved disease suppression to levels that were equivalent with the Thiram treatment in experiments 2 and 3 at the low level of pathogen inoculum, and in experiment 2 for the N4-5 extract plus GL-21 treatment. The N4-5 ethanol extract treatment was similar to the Thiram treatment in experiment 1 (Table 5). Combining the N4-5 ethanol extract seed treatment with a biological control agent also improved plant stand to that similar with the healthy check in a few situations in soil number 15 .

\section{Discussion}

Variation in soil factors, including aggregation, voids, chemistry, and resident microflora, can impose heterogeneous conditions on soil, with the end result being a spatially diverse collection of unique and localized microenvironments in an agricultural field (Smiles 1988; van Elsas and van Overbeek 1993). In soil, each microenvironment has

Table 5. Suppression of damping-off of cucumber caused by Pythium ultimum in natural soil number 15 with in-furrow applications of Trichoderma harzianum Th23::hyg-egfp, T. virens GL-21, or ethanol extract from Serratia marcescens N4-5 applied alone or in combination ${ }^{\mathrm{x}}$

\begin{tabular}{|c|c|c|c|c|c|}
\hline \multirow[b]{2}{*}{ Treatment $^{\mathrm{z}}$} & \multicolumn{5}{|c|}{ Mean plant stand per pot at different $P$. ultimum infestation levels ${ }^{y}$} \\
\hline & $\mathbf{0}$ & 10 & 20 & 30 & 60 \\
\hline \multicolumn{6}{|l|}{ Experiment 1} \\
\hline No treatment & $4.88 \mathrm{~A}$ & $0.50 \mathrm{IJ}$ & $\ldots$ & $0.63 \mathrm{IJ}$ & $\ldots$ \\
\hline N4-5 ethanol extract & $4.50 \mathrm{ABC}$ & $3.13 \mathrm{CDE}$ & $\ldots$ & $1.88 \mathrm{E}-\mathrm{I}$ & $\ldots$ \\
\hline N4-5 ethanol extract + Th23::hph-egfp & $4.75 \mathrm{~A}$ & $3.25 \mathrm{~B}-\mathrm{E}$ & $\ldots$ & $1.25 \mathrm{~F}-\mathrm{J}$ & $\ldots$ \\
\hline N4-5 ethanol extract + GL-21 & 4.38 ABC & $2.88 \mathrm{DE}$ & $\ldots$ & $4.13 \mathrm{~A}-\mathrm{D}$ & $\ldots$ \\
\hline N4-5 ethanol extract + Mycostop & $4.75 \mathrm{~A}$ & $2.38 \mathrm{EFG}$ & $\ldots$ & $0.88 \mathrm{HIJ}$ & $\ldots$ \\
\hline Th23::hph-egfp & $4.38 \mathrm{ABC}$ & 2.38 EFG & $\ldots$ & $0.00 \mathrm{~J}$ & $\ldots$ \\
\hline GL-21 & $4.88 \mathrm{~A}$ & $2.50 \mathrm{EF}$ & $\ldots$ & $1.00 \mathrm{G}-\mathrm{J}$ & $\ldots$ \\
\hline Mycostop & $4.50 \mathrm{ABC}$ & $1.00 \mathrm{G}-\mathrm{J}$ & $\ldots$ & $0.13 \mathrm{~J}$ & $\ldots$ \\
\hline Thiram & $4.88 \mathrm{~A}$ & $4.25 \mathrm{~A}-\mathrm{D}$ & $\ldots$ & $2.13 \mathrm{E}-\mathrm{H}$ & $\ldots$ \\
\hline Ethanol only & $4.63 \mathrm{AB}$ & $0.13 \mathrm{~J}$ & $\ldots$ & $0.25 \mathrm{~J}$ & $\ldots$ \\
\hline Sterile Biodac & $4.00 \mathrm{~A}-\mathrm{D}$ & $1.38 \mathrm{~F}-\mathrm{J}$ & $\ldots$ & $0.38 \mathrm{~J}$ & $\ldots$ \\
\hline Ethanol + sterile Biodac & $4.88 \mathrm{~A}$ & $1.38 \mathrm{~F}-\mathrm{J}$ & $\ldots$ & $0.13 \mathrm{~J}$ & $\ldots$ \\
\hline \multicolumn{6}{|l|}{ Experiment 2} \\
\hline No treatment & $4.63 \mathrm{~A}-\mathrm{D}$ & $4.88 \mathrm{AB}$ & $\ldots$ & $2.13 \mathrm{IJK}$ & $\ldots$ \\
\hline N4-5 ethanol extract & $4.63 \mathrm{~A}-\mathrm{D}$ & $3.63 \mathrm{C}-\mathrm{G}$ & $\ldots$ & $3.25 \mathrm{~F}-\mathrm{I}$ & $\ldots$ \\
\hline N4-5 ethanol extract + Th23::hph-egfp & $4.63 \mathrm{~A}-\mathrm{D}$ & $3.88 \mathrm{~A}-\mathrm{F}$ & $\ldots$ & $3.50 \mathrm{D}-\mathrm{H}$ & $\ldots$ \\
\hline N4-5 ethanol extract + GL-21 & $4.63 \mathrm{~A}-\mathrm{D}$ & $4.25 \mathrm{~A}-\mathrm{F}$ & $\ldots$ & $4.00 \mathrm{~A}-\mathrm{F}$ & $\ldots$ \\
\hline N4-5 ethanol extract + Mycostop & $4.50 \mathrm{~A}-\mathrm{E}$ & $4.50 \mathrm{~A}-\mathrm{E}$ & $\ldots$ & $3.75 \mathrm{~B}-\mathrm{F}$ & $\ldots$ \\
\hline Th23::hph-egfp & $4.88 \mathrm{AB}$ & $4.13 \mathrm{~A}-\mathrm{F}$ & $\ldots$ & $2.50 \mathrm{G}-\mathrm{J}$ & $\ldots$ \\
\hline GL-21 & $4.88 \mathrm{AB}$ & $4.38 \mathrm{~A}-\mathrm{F}$ & $\ldots$ & $1.13 \mathrm{~K}$ & $\ldots$ \\
\hline Mycostop & $4.38 \mathrm{~A}-\mathrm{F}$ & $4.38 \mathrm{~A}-\mathrm{F}$ & $\cdots$ & $1.13 \mathrm{~K}$ & $\cdots$ \\
\hline Thiram & $5.00 \mathrm{~A}$ & $4.88 \mathrm{AB}$ & $\ldots$ & $3.38 \mathrm{E}-\mathrm{H}$ & $\ldots$ \\
\hline Ethanol only & $4.63 \mathrm{~A}-\mathrm{D}$ & $3.63 \mathrm{C}-\mathrm{G}$ & $\ldots$ & $2.00 \mathrm{JK}$ & $\ldots$ \\
\hline Sterile Biodac & $4.25 \mathrm{~A}-\mathrm{F}$ & $4.50 \mathrm{~A}-\mathrm{E}$ & $\ldots$ & $1.63 \mathrm{JK}$ & $\ldots$ \\
\hline Ethanol + sterile Biodac & $4.50 \mathrm{~A}-\mathrm{E}$ & $4.75 \mathrm{ABC}$ & $\ldots$ & 2.38 HIJ & $\ldots$ \\
\hline \multicolumn{6}{|l|}{ Experiment 3} \\
\hline No treatment & $4.88 \mathrm{~A}$ & $\ldots$ & $1.13 \mathrm{GHI}$ & $\ldots$ & $0.00 \mathrm{I}$ \\
\hline N4-5 ethanol extract & $4.63 \mathrm{AB}$ & $\ldots$ & $1.75 \mathrm{FG}$ & $\ldots$ & $1.38 \mathrm{FGH}$ \\
\hline N4-5 ethanol extract + Th23::hph-egfp & $4.75 \mathrm{AB}$ & $\ldots$ & $2.50 \mathrm{EF}$ & $\ldots$ & $0.25 \mathrm{HI}$ \\
\hline N4-5 ethanol extract + GL-21 & $4.38 \mathrm{ABC}$ & $\ldots$ & $1.75 \mathrm{FG}$ & $\ldots$ & $1.13 \mathrm{GHI}$ \\
\hline N4-5 ethanol extract + Mycostop & $4.00 \mathrm{~A}-\mathrm{D}$ & $\ldots$ & $3.25 \mathrm{CDE}$ & $\ldots$ & $0.75 \mathrm{GHI}$ \\
\hline Th23::hph-egfp & $4.38 \mathrm{ABC}$ & $\ldots$ & $0.25 \mathrm{HI}$ & $\ldots$ & $0.00 \mathrm{I}$ \\
\hline GL-21 & $4.63 \mathrm{AB}$ & $\cdots$ & $0.75 \mathrm{GHI}$ & $\cdots$ & $0.88 \mathrm{GHI}$ \\
\hline Mycostop & $4.13 \mathrm{~A}-\mathrm{D}$ & $\ldots$ & $0.50 \mathrm{HI}$ & $\ldots$ & $0.13 \mathrm{I}$ \\
\hline Thiram & $4.75 \mathrm{AB}$ & $\ldots$ & $3.63 \mathrm{~B}-\mathrm{E}$ & $\ldots$ & $1.13 \mathrm{GHI}$ \\
\hline Ethanol only & $4.38 \mathrm{ABC}$ & $\ldots$ & $1.13 \mathrm{GHI}$ & $\ldots$ & $0.00 \mathrm{I}$ \\
\hline Sterile Biodac & $3.00 \mathrm{DE}$ & $\ldots$ & $0.13 \mathrm{I}$ & $\ldots$ & $0.38 \mathrm{HI}$ \\
\hline Ethanol + sterile Biodac & $3.00 \mathrm{DE}$ & $\cdots$ & $0.13 \mathrm{I}$ & $\cdots$ & $0.13 \mathrm{I}$ \\
\hline
\end{tabular}

${ }^{\mathrm{x}}$ Inoculum was applied in soil number 15 (loam soil, $\mathrm{pH}$ 5.1, 1.4\% organic matter) using an inoculum sandwich technique, where treatments and seed were sandwiched between layers of natural soil number 15 containing sporangia of $P$. ultimum which were, in turn, on top of a layer of potting mix. Trichoderma isolates were applied in-furrow as a drench to the seed area. In-furrow application delivered approximately $10^{7}$ hygromycin-resistant, Trichoderma-like CFU to the seed region. The N4-5 ethanol extract was applied as a seed treatment.

y $P$. ultimum was added at $0,10,20,30$, or 60 sporangia $/ \mathrm{cm}^{3}$ of soil inoculum. Values are the mean of eight replicates, each containing 5 seeds, expressed as mean plant stand per pot. Numbers followed by the same letter are not significantly different $(P \leq 0.05)$ for that experiment as determined by a protected least significant difference test. Least significant difference was 1.383 for experiment $1,1.183$ for experiment 2 , and 1.193 for experiment 3 . Data from experiments could not be combined because there was a significant experiment-treatment effect $(P<0.001)$.

${ }^{\mathrm{z}}$ See Materials and Methods for a complete description of treatments. No treatment indicates that cucumber seed were not treated prior to being sown and there were no in-furrow applications. 
the potential to influence the performance of biologically based controls in different ways (Roberts and Kobayashi 2011). Therefore, biologically based controls must be tested for disease suppression capabilities in a variety of different soils and other planting media. In prior work, we demonstrated that cell-free ethanol extract of Serratia marcescens N4-5 provided suppression of damping-off of cucumber caused by $P$. ultimum that was equivalent to the seed treatment pesticide Thiram when experiments were performed in commercial potting mix (Roberts et al. 2007, 2014). Thiram was used because cucumber seed treated with mefenoxam was not readily available. Here, we extended our testing of this ethanol extract to two natural soils. Soil number 11 was a sandy loam, pH 5.1, with $4.8 \%$ organic matter, while soil number 15 was a loam, pH 5.1, with $1.4 \%$ organic matter. There were clear differences in the performance of the N4-5 ethanol extract seed treatment and the other treatments in these two soils (Tables 4 and 5). The N4-5 ethanol extract, when applied as a seed treatment, performed well in soil number 11 but not in soil number 15 . The Thiram seed treatment also did not perform well in soil number 15 . It is not known why control of damping-off of cucumber with ethanol extract- or Thiram-treated seed was not consistent among these two soils but it is not likely that nontarget pathogens contributed to this inconsistent performance. The plant stand associated with the nontreated healthy check was unaffected in these two soils, being similar to that associated with this treatment in potting mix (Tables 2, 3, 4, and 5). It is more likely that other soil factors contributed to this inconsistent performance. Soil number 15 appeared to be somewhat more conducive to disease caused by P. ultimum than soil number 11. Texture, organic matter, activity of resident microbes, and so on are thought to influence disease caused by Pythium spp. (Boehm and Hoitink 1992; Craft and Nelson 1996; Hancock 1979). It is possible that factors in soil number 15 making this soil more conducive to disease than soil number 11 or the impact of different biotic and abiotic components in this soil on N4-5 ethanol extract and Thiram were responsible for this variation in performance of these treatments.

Overcoming inconsistent performance by biologically based controls at the field scale is necessary if they are to become widespread in production agriculture (Fravel 2005; Glare et al. 2012). Approaches to overcoming inconsistent performance by biologically based controls include their integration into multitactic disease management strategies, where different biologically based controls are combined, such as with microbial biological control agents (Lemanceau and Alabouvette 1991; Pierson and Weller 1994; Raupach and Kloepper 1998; Roberts and Kobayashi 2011). However, several researchers have indicated that components of these multitactic, biologically based controls must be compatible for increased disease suppression to occur (Baker 1990; Janisiewicz 1996; Janisiewicz and Bors 1995; Raupach and Kloepper 1998). Incompatibility among these components is possible because these components are typically selected based on their general antagonistic activity toward microbes (Leeman et al. 1996; Meyer and Roberts 2002; Roberts et al. 2005; Xu et al. 2011). For example, inhibitory metabolites produced by isolates of Serratia include pyrrolnitrin, oocydin A, carbapenem, prodigiosin, and serrawettin as well as chitinase and other cell-wall- and cellmembrane-degrading enzymes (Asano et al. 1999; Kamensky et al. 2003; Lindum et al. 1998; McGowan et al. 1999; Strobel et al. 1999). At least one of these compounds, prodigiosin, has been reported to have broad-spectrum antibiotic activity, including antifungal, antibacterial, antiprotozoal, and anti-insectal activity (Patil et al. 2013; Someya et al. 2001; Tsuji et al. 1992; Williams and Quadri 1980). The N4-5 ethanol extract tested in this study contained prodigiosin and potentially other compounds with broad-spectrum antibiotic activity (Roberts et al. 2007).

Here, we demonstrated the compatibility of the N4-5 ethanol extract with two Trichoderma isolates, Th23::hph-egfp and GL-21, that have been used for control of soilborne diseases of vegetables and other crops (Table 1). The N4-5 ethanol extract was compatible with these isolates despite possible in vitro inhibition by N4-5 ethanol extract-soaked filter paper on agar challenge plates. Isolates Th23:: hph-egfp and GL-21 were capable of colonizing the cucumber seed coat and developing root in vitro when seed was treated with the ethanol extract. There was no evidence of inhibition of cucumber rhizosphere colonization by Th23::hph-egfp in situ in potting mix due to seed treatment with the N4-5 ethanol extract, and control of dampingoff of cucumber caused by P. ultimum was not reduced when seed treatments with the ethanol extract were combined with seed treatment or in-furrow application of Th23::hph-egfp or GL-21 in experiments conducted in potting mix or two natural soils (Tables 2, 3, 4, and 5). Further experiments need to be conducted to determine whether combining the ethanol extract seed treatment with Trichoderma spp. or other biological control fungi improves consistency of disease control performance, although there was some evidence of this in experiments reported here (Tables 4 and 5). These assays need to be conducted in several soils with and without amendments of additional pathogens of cucumber. These assays should be conducted where these soils are the only planting medium so that the pathogens have the opportunity to infect plant tissue distant from the point of seed treatment, something not allowed for with the inoculum sandwich technique used in this study.

Seed treatment with the N4-5 ethanol extract has potential for use in conventional production systems because cucumber seed treated with the extract were protected in certain planting media at levels similar to that provided by a commercial pesticide and also had a shelf-life of at least 14 weeks, as reported here and elsewhere (Roberts et al. 2014). The N4-5 ethanol extract, or components thereof, may provide additional modes of action for control of $P$. ultimum in conventional production systems. Several fungicide groups with diverse modes of action are currently available for the control of oomycete diseases, including phenylamides (metylaxyl), quinone outside inhibitors, and carboxylic acid amides (Bi et al. 2014). However, populations of oomycetes resistant to these pesticides have been detected (Cohen and Coffey 1986; Gisi and Sierotzki 2008; Gisi et al. 2011). Additionally, it may be possible to use the inhibitory components of the N4-5 ethanol extract as is, or a chemically modified derivative, as was done with pyrrolnitrin for the development of fenpiclonil and fludioxonil (Gale et al. 2005; Ligon et al. 2000). Seed treatment with this extract also has potential in organic production systems because this application of ethanol is approved by the Organic Materials Review Institute for use in organic crop production (www.omri.org/omri-lists).

\section{Acknowledgments}

We thank S. Kang, Department of Plant Pathology and Environmental Microbiology, Pennsylvania State University, University Park for supplying Agrobacterium tumefaciens AGL-1.

\section{Literature Cited}

Abawi, G. A. 1991. Effect of tillage practices on root rot severity and yield on snap beans. Annu. Rep. Bean Improv. Coop. 34:56-57.

Asano, S., Ogiwara, K., Nakagawa, Y., Suzuki, K., Hori, H., and Watanabe, T. 1999. Prodigiosin produced by Serratia marcescens enhances the insecticidal activity of Bacillus thuringiensis delta endotoxin (Cry1C) against common cutworm, Spodoptera litura. J. Pest Sci. 24:381-385.

Ayers, W. A., and Lumsden, R. D. 1975. Factors affecting production and germination of oospores of three Pythium species. Phytopathology 65:1094-1100.

Baker, R. 1990. An overview of current and future strategies and models for biological control. Pages 375-388 in: Biological Control of Soil-borne Plant Pathogens. D. Hornby, ed. CAB International, Wallingford, UK.

Bi, Y., Chen, L., Cai, M., Zhu, S., Pang, Z., and Liu, X. 2014. Two non-target recessive genes confer resistance to the anti-oomycete microtubule inhibitor zoxamide in Phytophthora capsici. PLoS One 9:e89336.

Boehm, M. J., and Hoitink, H. A. J. 1992. Sustenance of microbial activity in potting mixes and its impact on severity of Pythium root rot of Poinsettia. Phytopathology 82:259-264.

Bonanomi, G., Antignani, V., Pane, C., and Scala, F. 2007. Suppression of soilborne fungal diseases with organic amendments. J. Plant Pathol. 89: 311-324.

Chen, X., Stone, M., Schlagnhaufer, C., and Romaine, C. P. 2000. A fruiting body tissue method for efficient Agrobacterium-mediated transformation of Agaricus bisporus. Appl. Environ. Microbiol. 66:4510-4513.

Cohen, Y., and Coffey, M. D. 1986. Systemic fungicides and the control of oomycetes. Annu. Rev. Phytopathol. 24:311-338.

Craft, C. M., and Nelson, E. B. 1996. Microbial properties of compost that suppress damping-off and root rot of creeping bentgrass caused by Pythium graminicola Appl. Environ. Microbiol. 62:1550-1557. 
Fravel, D. R. 2005. Commercialization and implementation of biocontrol. Annu. Rev. Phytopathol. 43:337-359.

Fukui, R., Campbell, G. S., and Cook, R. J. 1994. Factors influencing the incidence of embryo infection by Pythium spp. during germination of wheat seeds in soils. Phytopathology 84:695-702.

Gale, P. A., Light, M. E., McNally, B., Navakhun, K., Sliwinskia, K. E., and Smith, B. D. 2005. Co-transport of $\mathrm{H}+/ \mathrm{Cl} 2$ by a synthetic prodigiosin mimic. Chem. Commun. (Camb.) 30:3773-3775.

Garzón, C. D., Molineros, J. E., Yánez, J. M., Flores, F. J., del Mar Jiménez-Gasco, M., and Moorman, G. W. 2011. Sublethal doses of Mefenoxam enhance Pythium damping-off of geranium. Plant Dis. 95:1233-1238.

Gisi, U., Lamberth, C., Mehl, A., and Seitz, T. 2011. Carboxylic acid amide (CAA) fungicides. Pages 807-830 in: Modern Crop Protection Compounds, Vol. 1-3, Second Edition. W. Krämer, U. Schirmer, P. Jeschke, and M. Witschel, eds. Wiley-VCH Verlag GmbH \& Co. KGaA, Weinheim, Germany.

Gisi, U., and Sierotzki, H. 2008. Fungicide modes of action and resistance in downy mildews. Eur. J. Plant Pathol. 122:157-167.

Glare, T., Caradus, J., Gelernter, W., Jackson, T., Keyhani, N., Köhl, J., Marrone, P., Morin, L., and Stewart, A. 2012. Have biopesticides come of age? Trends Biotechnol. 30:250-258.

Hadar, Y., Harman, G. E., Taylor, A. G., and Norton, G. M. 1983. Effects of pregermination of pea and cucumber seeds and of seed treatment with Enterobacter cloacae on rots caused by Pythium spp. Phytopathology 73: 1322-1325.

Hancock, J. G. 1979. Occurrence of soil suppressive to Pythium ultimum. Pages 183-189 in: Soil-Borne Plant Pathogens. B. Schippers and W. Gams, eds. Academic Press, New York.

Handelsman, J., and Stabb, E. V. 1996. Biocontrol of plant pathogens. Plant Cell 8: 1855-1869.

Harman, G. E., Howell, C. R., Viterbo, A., Chet, I., and Lorito, M. 2004. Trichoderma species-Opportunistic, avirulent plant symbionts. Nat. Rev. Microbiol. 2:43-56.

Howell, C. R. 2003. Mechanisms employed by Trichoderma species in the biological control of plant diseases: The history and evolution of current concepts. Plant Dis. 87:4-10.

Janisiewicz, W. 1996. Ecological diversity, niche overlap, and coexistence of antagonists used in developing mixtures for biocontrol of postharvest diseases of apples. Phytopathology 86:473-479.

Janisiewicz, W., and Bors, B. 1995. Development of a microbial community of bacterial and yeast antagonists to control wound invading postharvest pathogens of fruits. Appl. Environ. Microbiol. 61:3261-3267.

Kamensky, M., Ovadis, M., Chet, I., and Chernin, L. 2003. Soil-borne strain IC14 of Serratia plymuthica with multiple mechanisms of antifungal activity provides biocontrol of Botrytis cinerea and Sclerotinia sclerotiorum diseases. Soil Biol. Biochem. 35:323-331.

Kamoun, S., Furzer, O., Jones, J. D. G., Judelson, H. S., Ali, G. S., Dalio, R. J. D., Roy, S. G., Schena, L., Zambounis, A., Panabières, F., Cahill, D., Ruocco, M., Figueiredo, A., Chan, X.-R., Hulvey, J., Stam, R., Lamour, K., Gijzen, M., Tyler, B. M., Grünwald, N. J., Mukhtar, M. S., Tomé, D. F. A., Tör, M., Van Den Ackerveken, G., McDowell, J., Daayf, F., Fry, W. E., Lindqvist-Kreuze, H., Meijer, H. J. G., Petre, B., Ristaino, J., Yoshida, K., Birch, P. R. J., and Govers, F. 2015. The top 10 oomycete pathogens in molecular plant pathology. Mol. Plant Pathol. 16:413-434.

Kemppainen, M., Circosta, A., Tagu, D., Martin, F., and Pardo, A. G. 2005. Agrobacterium-mediated transformation of the ectomycorrhizal symbiont Laccaria bicolor S238N. Mycorrhiza 16:19-22.

Khang, C., Park, S., Rho, H., Lee, Y., and Kang, S. 2006. Agrobacterium tumefaciens-mediated transformation and mutagenesis of filamentous fungi Magnaporthe grisea and Fusarium oxysporum. Pages 403-420 in: Agrobacterium Protocols. K. Wang, ed. Humana Press, Totowa, NJ.

Kobayashi, D. Y., and El-Barrad, N. 1996. Selection of bacterial antagonists using enrichment cultures for the control of summer patch disease in Kentucky Bluegrass. Curr. Microbiol. 32:106-110.

Lakshman, D. K., Pandey, R., Kamo, K., Bauchan, G., and Mitra, A. 2011. Genetic transformation of Fusarium oxysporum f. sp. gladioli with Agrobacterium to study pathogenesis in Gladiolus. Eur. J. Phytopathol. 133:729-738.

Lamour, K. H., and Hausbeck, M. K. 2000. Mefenoxam insensitivity and the sexual stage of Phytophthora capsici in Michigan cucurbit fields. Phytopathology 90:396-400.

Leeman, M., Den Ouden, F. M., Van Pelt, J. A., Matamala-Garros, A., Bakker, P. A. H. M., and Schippers, B. 1996. Suppression of Fusarium wilt of radish by co-inoculation of fluorescent Pseudomonas spp. and root-colonizing fungi. Eur. J. Plant Pathol. 102:21-31.

Lemanceau, P., and Alabouvette, C. 1991. Biological control of Fusarium diseases by fluorescent Pseudomonas and non-pathogenic Fusarium. Crop Prot. 10:279-286.

Lewis, J. A., Lumsden, R. D., Papavizas, G. C., and Kantzes, J. G. 1983. Integrated control of snap bean diseases caused by Pythium spp., and Rhizoctonia solani. Plant Dis. 67:1241-1244.

Ligon, J. M., Hill, D. S., Hammer, P. E., Torkewitz, N. R., Hofmann, D., Kempf, H.-J., and van Pée, K.-H. 2000. Natural products with antifungal activity from Pseudomonas biocontrol bacteria. Pest Manage. Sci. 56:688-695.

Lindum, P. W., Anthoni, U., Christophersen, C., Eberl, L., Molin, S., and Givskov, M. 1998. N-acyl-L-homoserine lactone autoinducers control production of an extracellular lipopeptide biosurfactant required for swarming motility of Serratia liquefaciens MG1. J. Bacteriol. 180:6384-6388.

Louws, F. J., Rivard, C. L., and Kubota, C. 2010. Grafting fruiting vegetables to manage soilborne pathogens, foliar pathogens, arthropods and weeds. Sci. Hortic. (Amsterdam) 127:127-146.

Lucas, B., and Griffiths, P. D. 2004. Evaluation of common bean accessions for resistance to Pythium ultimum. HortScience 39:1193-1195.

Matsuyama, T., Fujita, M., and Yano, I. 1985. Wetting agent produced by Serratia marcescens. FEMS Microbiol. Lett. 28:125-129.

McGowan, S. J., Holden, T. G., Bycroft, B. W., and Salmond, G. P. C. 1999 Molecular genetics of carbapenem antibiotic biosynthesis. Antonie Leeuwenhoek 75:135-141

Meyer, S. L. F., and Roberts, D. P. 2002. Combinations of biocontrol agents for management of plant-parasitic nematodes and soilborne plant-pathogenic fungi. J. Nematol. 34:1-8

Moorman, G. W., and Kim, S. H. 2004. Species of Pythium from greenhouses in Pennsylvania exhibit resistance to propamocarb and mefenoxam. Plant Dis. 88:630-632.

Mosquera, G., Giraldo, M. C., Khang, C. H., Coughlan, S., and Valent, B. 2009 Interaction transcriptome analysis identifies Magnaporthe oryzae BAS1-4 as biotrophy-associated secreted proteins in rice blast disease. Plant Cell 21: 1273-1290.

Mullins, E., Chen, X., Romaine, P., Raina, R., Geiser, D., and Kang, S. 2001 Agrobacterium-mediated transformation of Fusarium oxysporum: An efficient tool for insertional mutagenesis and gene transfer. Phytopathology 91:173-180.

Nelson, E. B. 1988. Biological control of Pythium seed rot and preemergence damping-off of cotton with Enterobacter cloacae and Erwinia herbicola applied as seed treatments. Plant Dis. 72:140-142.

Nelson, E. B. 1990. Exudate molecules initiating fungal responses to seeds and roots. Plant Soil 129:61-73.

Nelson, E. B. 2004. Microbial dynamics and interactions in the spermosphere. Annu. Rev. Phytopathol. 42:271-309.

Okubara, P. A., Dickman, M. B., and Blechl, A. E. 2014. Molecular and genetic aspects of controlling the soilborne necrotrophic pathogens Rhizoctonia and Pythium. Plant Sci. 228:61-70.

Patil, N. G., Kadam, M. S., Patil, V. R., and Chincholkar, S. B. 2013. Insecticidal properties of water diffusible prodigiosin produced by Serratia nematodiphila 213c. Curr. Trends Biotechnol. Pharm. 7:773-781.

Pierson, E. A., and Weller, D. M. 1994. Use of mixtures of fluorescent pseudomonads to suppress take-all and improve the growth of wheat. Phytopathology 84:940-947.

Raupach, G. S., and Kloepper, J. W. 1998. Mixtures of plant growth-promoting rhizobacteria enhance biological control of multiple cucumber pathogens. Phytopathology 88:1158-1164.

Roberts, D. P., Dery, P. D., Hebbar, P. K., Mao, W., and Lumsden, R. D. 1997. Biological control of damping-off of cucumber caused by Pythium ultimum with a root-colonization-deficient strain of Escherichia coli. J. Phytopathol. 145:383-388.

Roberts, D. P., and Kobayashi, D. Y. 2011. Impact of spatial heterogeneity within spermosphere and rhizosphere environments on performance of bacterial biological control agents. Pages 111-130 in: Bacteria in Agrobiology: Crop Ecosystems. D. K. Maheshwari, ed. Springer-Verlag, Berlin Heidelberg.

Roberts, D. P., Lakshman, D. K., Maul, J. E., McKenna, L. F., Buyer, J. S., and Fan, B. 2014. Control of damping-off of organic and conventional cucumber with extracts from a plant-associated bacterium rivals a seed treatment pesticide. Crop Prot. 65:86-94.

Roberts, D. P., Lohrke, S. M., Meyer, S. L. F., Buyer, J. S., Bowers, J. H., Baker C. J., Li, W., de Souza, J. T., Lewis, J. A., and Chung, S. 2005. Biocontrol agents applied individually and in combination for suppression of soilborne diseases of cucumber. Crop Prot. 24:141-155.

Roberts, D. P., Maul, J. E., McKenna, L. F., Emche, S. E., Meyer, S. L. F., Collins, R. T., and Bowers, J. H. 2010. Selection of genetically diverse Trichoderma spp. isolates for suppression of Phytophthora capsici on bell pepper. Can. J. Microbiol. 56:864-873.

Roberts, D. P., McKenna, L. F., Lakshman, D. K., Meyer, S. L. F., Kong, H., de Souza, J. G., Lydon, J., Baker, C. J., and Chung, S. 2007. Suppression of damping-off of cucumber caused by Pythium ultimum with live cells and extracts of Serratia marcescens. Soil Biol. Biochem. 39:2275-2288.

Smiles, D. E. 1988. Aspects of the physical environment of soil organisms. Biol. Fertil. Soils 6:204-215

Someya, N., Nakajima, M., Hirayae, K., Hibi, T., and Akutsu, K. 2001. Synergistic antifungal activity of chitinolytic enzymes and prodigiosin produced by biocontrol bacterium, Serratia marcescens strain B2 against gray mold pathogen, Botrytis cinerea. J. Gen. Plant Pathol. 67:312-317.

Stanghellini, M. E. 1974. Spore germination, growth, and survival of Pythium in soil. Proc. Am. Phytopathol. Soc. 1:211-214.

Stanghellini, M. E., and Hancock, J. G. 1971. The sporangium of Pythium ultimum as a survival structure in soil. Phytopathology 61:157-164.

Stone, A. G., Traina, S. J., and Hoitink, H. A. 2001. Particulate organic matter composition and Pythium damping-off of cucumber. Soil Sci. Soc. Am. J. 65:761-770.

Strobel, G., Li, J.-Y., Sugawara, F., Koshino, H., Harper, J., and Hess, W. M. 1999. Oocydin A, a chlorinated macrocyclic lactone with potent anti-oomycete activity from Serratia marcescens. Microbiology 145:3557-3564. 
Sumner, D. R., Smittle, D. A., Thredgill, E. A., Johnson, A. W., and Chalfant, R. B. 1986. Interactions of tillage and soil fertility with root diseases in snap bean and lima bean in irrigated multiple-cropping systems. Plant Dis. 70:730-735.

Taylor, R. J., Salas, B., Secor, G. A., Rivera, V., and Gudmestad, N. C. 2002. Sensitivity of north American isolates of Phytophthora erythroseptica and Pythium ultimum to mefenoxam (metalaxyl). Plant Dis. 86:797-802.

Termorshuizen, A. J., van Rijn, E., van der Gaag, D. J., Alabouvette, C., Chen, Y., Lagerlof, J., Malandrakis, A. A., Paplomatas, E. J., Ramer, B., and Ryckerboer, J. 2006. Suppressiveness of 18 composts against 7 pathosystems: Variability in pathogen response. Soil Biol. Biochem. 38:2461-2477.

Tsuji, R. F., Magae, J., Yamashita, M., Nagai, K., and Yamasaki, M. 1992. Immunomodulating properties of prodigiosin $25-\mathrm{C}$, an antibiotic which preferentially suppresses induction of cytotoxic T cells. J. Antibiot. (Tokyo) 45:1295-1302.

van Elsas, J. D., and van Overbeek, L. S. 1993. Bacterial responses to soil stimuli. Pages 55-79 in: Starvation in Bacteria. S. Kjelleberg, ed. Plenum Press, New York.
Wang, H. P., and Davis, R. M. 1997. Susceptibility of selected cotton cultivars to seedling disease pathogens and benefits of chemical seed treatments. Plant Dis. 81:1085-1088.

Williams, R. P., and Quadri, S. M. 1980. The pigments of Serratia. Pages 31-75 in The Genus Serratia. A. Von Graevenitz and S. J. Rubin, eds. CRC Press, Boca Raton, FL.

Windstam, S., and Nelson, E. B. 2008. Differential interference with Pythium ultimum sporangium activation and germination by Enterobacter cloacae in the corn and cucumber spermospheres. Appl. Environ. Microbiol. 74:4285-4291.

Xi, K., Stephens, J. H. G., and Hwang, S. F. 1995. Dynamics of pea seed infection by Pythium ultimum and Rhizoctonia solani-Effects of inoculums density and temperature on seed rot and preemergence damping-off. Can. J. Plant Pathol. 17:19-24.

Xu, X.-M., Jeffries, P., Pautasso, M., and Jeger, M. J. 2011. Combined use of biocontrol agents to manage plant diseases in theory and practice. Phytopathology 101:1024-1031. 